\title{
Analisis Pengaruh Kewajiban Penyediaan Modal Minimum (KPMM), Beban Operasional Pendapatan Operasional (BOP0), Financing To Deposit Ratio (FDR), Dan Inflasi Terhadap Return On Asset (ROA) Pada Bank Umum Syariah Di Indonesia Periode 2016-2019
}

\author{
Muhammad Hilda Al iqbal ${ }^{1}$, Iwan Budiyanto ${ }^{2}$ \\ 1,2Politeknik Negeri Semarang, Semarang \\ $\bowtie$ hildaaliqbal82@gmail.com
}

\begin{abstract}
Penelitian ini bertujuan untuk menganalisis dan mendapatkan bukti empiris mengenai pengaruh KPMM, BOPO, FDR, dan Inflasi terhadap ROA pada Bank Umum Syariah di Indonesia periode 2016-2019. Metode yang digunakan adalah Analisis Regresi Linear Berganda dengan teknik analisis Uji F, Uji R2, dan Uji t. Berdasarkan hasil pengujian dan pembahasan diperoleh hasil $K P M M, B O P O, F D R$, dan Inflasi secara simultan berpengaruh signifikan terhadap besar Return on Asset (ROA) Bank Umum Syariah di Indonesia. Secara parsial, BOPO dan FDR memberikan pengaruh yang signifikan terhadap Return on Asset (ROA). Sedangkan, KPMM dan Inflasi tidak berpengaruh signifikan terhadap Return on Asset (ROA) pada Bank Umum Syariah di Indonesia.
\end{abstract}

Keywords $\quad$ : ROA; KPMM; BOPO; FDR; Inflasi.

\section{LATAR BELAKANG}

Perkembangan pekonomian di dunia sampai saat ini tidak dapat dipisahkan dari aktivitas perbankan. Apabila dihubungkan dengan pendanaan, hampir semua aktivitas perekonomian menggunakan perbankan sebagai lembaga keuangan yang dapat membantu berjalannya usaha tersebut. Semakin baik aktivitas perbankan di suatu negara, maka semakin baik pula kondisi perekonomian negara tersebut. Lembaga keuangan mempunyai peran yang sangat besar dalam kemajuan perekonomian suatu negara. Sistem yang stabil menggerakkan investor untuk berinvestasi, menerima laba, memperkuat kapabilitas sistem pada lembaga keuangan tersebut (Rahman, dkk, 2012).

Di Indonesia saat ini organisasi bisnis islam yang berkembang salah satunya adalah bank syariah. Pada perbankan syariah, bank berperan sebagai manajer investasi dari pemilik dana atas investasi yang disimpan di bank. Hubungan antara bank syariah dengan nasabah dalam praktek perbankan syariah bersifat kemitraan. Salah satu penyebab yang menjadikan bank syariah terus mengalami peningkatan adalah mekanisme pembagian keuntungannya yang berdasarkan prinsip bagi hasil (Almunawarroh dan Marliana, 2018).

Menurut UU No.21 Tahun 2008, bank syariah adalah bank yang menjalankan kegaiatan usahanya berdasarkan prinsip syariah dan menurut jenisnya terdiri dari Bank Umum Syariah dan Bank Pembiayaan Rakyat Syariah. Perkembangan Bank Syariah di Indonesia sudah memasuki dekade ke 3. Sejak pertama kali muncul pada tahun 1992 yaitu Bank Muamalat Indonesia (BMI), beberapa Bank Syariah lainnya pun bermunculan. Otoritas Jasa Keuangan (OJK) mencatat bahwa Hingga Juni 2019 
Bank Syariah di Indonesia berjumlah 13 Bank Umum Syariah (BUS), 21 Unit Usaha Syariah (UUS), dan 168 Bank Pembiayaan Rakyat Syariah (BPRS).

Menurut Muhammad (2014) terkait dengan fungsi dan peran lembaga perbankan, maka secara khusus bank syariah secara nyata dapat terwujud dalam aspek-aspek, yaitu menjadi perekat nasionalisme baru, memberdayakan ekonomi umat dan beroperasi secara transparan, memberikan return yang lebih baik. mendorong penurunan spekulasi di pasar keuangan dan mendorong pemerataan pendapatan.

Profitabilitas merupakan indikator untuk mengukur kinerja suatu bank. Profitabilitas menggambarkan kemampuan perusahaan dalam mendapatkan laba melalui semua kemampuan dan sumber yang ada seperti kegiatan penjulan, kas, modal, jumlah karyawan, jumlah cabang, dan sebagainya (Harahap, 2013). Bank Indonesia telah menetapkan salah satu ukuran profitabilitas suatu bank adalah Return on Asset (ROA).

Return on Asset (ROA) pada perbankan syariah dapat dipengaruhi oleh beberapa faktor, baik internal maupun eksternal. Faktor internal yang mungkin bisa mempengaruhi ROA diantaranya adalah Kewajiban Penyediaan Modal Minimum (KPMM), Beban Operasional terhadap Pendapatan Operasioanl, dan Financing to Deposit Ratio (FDR). Sedangkan untuk faktor eksternal, keadaan ekonomi suatu negara yang tidak stabil seperti terjadinya inflasi juga memungkinkan berpengaruh pada nilai ROA perbankan syariah. Faktor-faktor tersebut memiliki hubungan dan pengaruh terhadap Return on Asset (ROA).

Faktor yang pertama adalah Kewajiban Penyediaan Modal Minimum (KPMM). Kewajiban Penyediaan Modal Minimum (KPMM) adalah rasio yang berkaitan dengan permodalan bank untuk mengukur kecukupan modal yang dimiliki bank untuk menunjang aktiva yang mengandung risiko.

Faktor kedua yang bisa jadi mempengaruhi ROA adalah Beban Operasional terhadap Pendapatan Operasional. Mengingat aktivitas utama bank pada dasarnya adalah bertindak sebagai perantara keuangan (financial intermediary), yaitu menerima dan menyalurkan dana masyarakat, maka bank harus dapat menjaga kepercayaan masyarakat dengan menjamin tingkat likuiditas, juga beroperasi secara efektif dan efisien untuk memperoleh laba yang tinggi guna keberlangsungan usaha (Ismail, 2010).

Faktor internal lain yang juga dapat berpengaruh terhadap tinggi rendahnya ROA yakni Financing to Deposit Ratio (FDR). Financing to Deposit Ratio adalah rasio seluruh jumlah pembiayaan yang diberikan bank dengan dana yang diterima oleh bank. Jika rasio tersebut semakin tinggi maka dapat memberikan indikasi semakin rendahnya kemampuan likuiditas bank yang bersangkutan. Berkurangnya tingkat likuiditas dapat memberikan dampak terhadap naiknya profitabilitas (Almunawwaroh dan Marliana, 2018).

Rasio yang ada pada bank syariah juga dapat dipengaruhi oleh kondisi ekonomi makro dalam keputusan pengambilan kebijakan yang berkaitan dengan kinerja keuangan perbankan. Kondisi makro ekonomi yang dapat berpengaruh terhadap kinerja keuangan perbankan syariah di Indonesia, yaitu Inflasi, BI Rate, Kurs dan Produk Domestik Bruto yang merupakan beberapa faktor eksternal yang bisa saja berpengaruh terhadap profitabilitas suatu bank (Setyaningsih, et.al., 2018). Bank Indonesia mendefinisikan Inflasi sebagai peningkatan harga barang secara umum dan terus menerus. Kenaikan harga dari satu atau dua barang saja tidak dapat disebut 
inflasi kecuali bila kenaikan itu terjadi secara luas (mengakibatkan kenaikan harga) pada barang lainnya.

\section{TEORI DAN METODE}

\subsection{Faktor yang mempengaruhi Return on Asset (ROA)}

Berdasarkan tinjauan pustaka dan penelitian-penelitian terdahulu yang telah dilakukan, maka dikembangkan model pemikiran teoritis yang mendasari penelitian ini. Penelitian ini menganalisis signifikansi pengaruh Kewajiban Penyediaan Modal Minimum (KPMM), Beban Operasional Pendapatan Operasional (BOPO), Financing to Deposit Ratio (FDR), dan Inflasi terhadap Return on Assets (ROA). Berikut model penelitian yang dikembangkan dalam penelitian ini ditunjukkan pada Gambar 2.1.

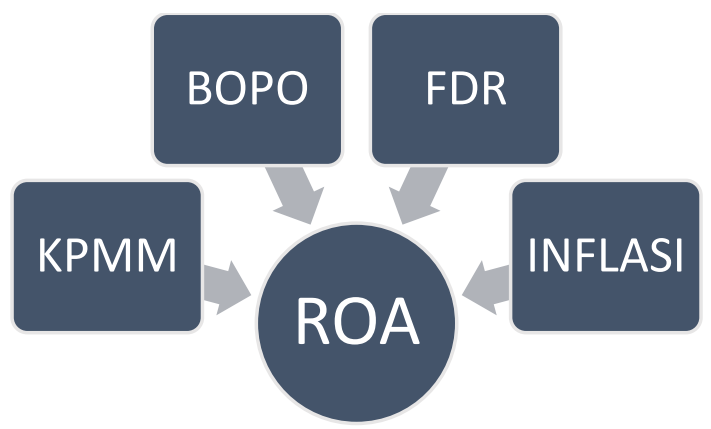

Gambar 2.1. Model Penelitian

\subsubsection{Return on Asset (ROA)}

Menurut Kasmir (2014:201), Return On Asset merupakan rasio yang menunjukkan hasil atas jumlah aktiva yang digunakan dalam perusahaan. Kenaikan dalam hal ini berarti terjadi kenaikan laba bersih dari bank yang bersangkutan.

Semakin besar Return on Assets menunjukkan kinerja keuangan yang semakin baik, karena tingkat kembalian semakin besar. Apabila Return on Assets meningkat, berarti profitabilitas perusahaan meningkat sehingga dampak akhirnya adalah peningkatan profitabilitas yang dinikmati oleh pemegang saham. Return on Assets (ROA) merupakan bagian dari rasio profitabilitas dalam menganalisa laporan keuangan atas laporan kinerja keuangan perusahaan. Dalam penentuan tingkat kesehatan suatu bank, Bank Indonesia lebih mementingkan penilaian besarnya ROA karena Bank Indonesia sebagai pembina dan pengawas perbankan lebih mengutamakan nilai profitabilitas suatu bank yang diukur dengan aset yang dananya sebagian besar berasal dari dana simpanan masyarakat (Dendawijaya, 2009).

\subsubsection{Kewajiban Penyediaan Modal Minimum (KPMM)}

Menurut Dendawijaya (2009) KPMM atau Capital Adequacy Ratio (CAR) adalah rasio yang memperlihatkan seberapa jauh seluruh aktiva bank yang mengandung risiko (kredit, penyertaan, surat berharga, tagihan pada bank lain) ikut dibiayai dari dana modal sendiri bank, disamping memperoleh danadana dari sumber-sumber di luar bank, seperti dana masyarakat, pinjaman (utang), dan lain-lain. Capital Adequacy Ratio adalah rasio kinerja bank untuk mengukur kecukupan modal yang dimiliki bank 
untuk mengukur kecukupan modal yang dimiliki bank untuk menunjang aktiva yang mengandung atau menghasilkan risiko, misalnya kredit yang diberikan. Rasio ini dapat dirumuskan sebagai berikut:

KPMM $=\frac{\text { Modal Sendiri }}{\text { ATMR }} \times 100 \%$

KPMM merupakan indikator terhadap kemampuan bank untuk menutupi penurunan aktivanya sebagai akibat dari kerugian-kerugian bank yang disebabkan oleh aktiva yang berisiko.

\subsubsection{Beban Operasional Pendapatan Operasional (BOPO)}

Kinerja operasional merupakan kemampuan bank dalam mengatur biaya dan pendapatan operasional yang dimilikinya. Rasio yang dapat digunakan untuk mengukur kinerja operasional suatu bank adalah rasio perbandingan antara biaya operasional terhadap pendapatan operasional (BOPO). Biaya operasional merupakan biaya yang dikeluarkan oleh bank dalam rangka menjalankan aktivitas usaha utamanya seperti biaya bunga, biaya pemasaran, biaya tenaga kerja dan biaya operasi lainnya. Semakin kecil rasio ioni berarti semakin efisien biaya biaya operasional yang dikeluarkan bank yang bersangkutan (Harun, 2016).

Menurut Dendawijaya (2009: 119) BOPO adalah rasio perbandingan antara biaya operasional dengan pendapatan operasional. BOPO digunakan untuk mengukur tingkat efisiensi dan kemampuan bank dalam melakukan kegiatan operasinya. Semakin kecil rasio BOPO berarti semakin efisien biaya operasional yang dikeluarkan oleh bank yang bersangkutan, dan setiap peningkatan pendapatan operasiakan berakibat pada berkurangnya laba sebelulm pajak yang pada akhirnya akan menurunkan laba atau profitabilitas (ROA) bank yang bersangkutan. Rasio BOPO dapat dirumuskan sebagai berikut:

\section{BOPO = Biaya Operasional $/$ Pendapatan Operasional $x$ 100\%}

\subsubsection{Financing to Deposit Ratio (FDR)}

Financing to Deposit Ratio (FDR) adalah perbandingan antara pembiayaan yang diberikan oleh bank dangan dana pihak ke tiga yang berhasil dikerahkan (Rivai dan Arifin, 2010: 748). Dalam perbankan syariah FDR digunakan untuk mengukur tingkat efektivitas pembiayaan yang disalurkan. Sehingga apabila FDR meningkat, maka laba bank jugaakan meningkat dengan asumsi jika bank dapat menyalurkan pembiayaan secara efektif (Widyaningrum, 2015).

Financing to Deposit Ratio (FDR) dapat mempengaruhi tingkat profitabilitas Bank Syariah (Sumarlin, 2016). Dalam Surat Edaran Bank Indonesia Nomor 26/5/BPPP tanggal 2 Mei 1993, besarnya FDR ini ditetapkan oleh Bank Indonesia tidak boleh melebihi 110\%. Semakin tinggi FDR maka semakin tinggi dana yang disalurkan ke dana pihak ketiga. Dengan dana pihak ketiga yang disalurkan maka pendapatan atau profitabilitas semakin meningkat (Sumarlin, 2016). 
Besar kecilnya rasio FDR suatu bank akan mempengaruhi profitabilitas bank tersebut. Semakin besar jumlah dan yang disalurkan kepada nasabah dalam bentuk kredit, maka jumlah dana yang menganggur berkurang dan penghasilan yang diperoleh akan meningkat. Hal ini tentunya akan meningkatkan FDR sehingga profitabilitas bank juga meningkat. Menururt Dendawijaya (2009: 116) FDR adalah rasio antara sleuruh jumlah kredit yang diberikan bank dengan dana yang diterima oleh bank. Rasio ini menunjukkan salah satu penilaian likuiditas bank dan dapat dirumuskan sebagi berikut:

\section{FDR = Jumlah dana yg diberikan / Total DPK x 100\%}

\subsubsection{Inflasi}

Inflasi didefinisikan sebagai kecenderungan kenaikan harga secara umum. Kecenderungan yang dimaksud disini adalah bahwa kenaikan tersebut bukan terjadi sesaat. Misalnya, harga-harga menjelang lebaran, atau hari libur lainnya cenderung naik. Namun, setelah perayaan usai, masyarakat kembali hidup seperti semula, dan harga akan kembali ke kondisi semula (Djohanputro, 2006).

Inflasi juga didefinisikan dengan kenaikan harga-harga barang umum secara terus menurus. Ini tidak berarti bahwa harga-harga berbagai macam barang itu naik dengan presentse yang sama. Mungkin dapat terjadi karena kenaikan tersebut tidaklah bersamaan. Yang penting terjadi kenaikan harga umum barang-barang secara terusmenerus selama periode tertentu (Nopirin, 2000: 174). Singkatnya inflasi adalah gejala kenaikan harga barang-barang yang bersifat umum dan terus menerus (Rahardja dan Manurung, 2004). Di bidang moneter laju inflasi yang tinggi dan tidak terkendali dapat mengganggu upaya perbankan dalam mengerahkan dana masyarakat. Hal ini disebabkan karena tingkat inflasi yang tinggi menyebabkan tingkat suku bunga riil menjadi menurun. Fakta demikian akan mengurangi hasrat masyarakat untuk menabung sehingga pertumbuhan dana perbankan yang bersumber dar masyarkat akan menurun (Pohan, 2008).

\subsection{Hipotesis}

Berdasarkan pengaruh hubungan antar variabel, maka hipotesis yang diajukan dalam penelitian ini sebagai berikut:

$\mathrm{H}_{1}$ : Diduga Kewajiban Penyediaan Modal Minimum (KPMM), Biaya Operasional terhadap Pendapatan Operasional (BOPO), Financing to Deposit Ratio (FDR), dan Inflasi secara simultan berpengaruh signifikan terhadap Return on Assets (ROA) pada Bank Umum Syariah di Indonesia periode 2016-2019.

$\mathrm{H}_{2}$ : Diduga Kewajiban Penyediaan Modal Minimum (KPMM) secara parsial berpengaruh signifikan terhadap Return on Assets (ROA) pada Bank Umum Syariah di Indonesia periode 2016-2019.

$\mathrm{H}_{3}$ : Diduga Biaya Operasional terhadap Pendapatan Operasional (BOPO) secara parsial berpengaruh signifikan terhadap Return on Assets (ROA) pada Bank Umum Syariah di Indonesia periode 2016-2019. 
$\mathrm{H}_{4}$ : Diduga Financing to Deposit Ratio (FDR) secara parsial berpengaruh signifikan terhadap Return on Assets (ROA) pada Bank Umum Syariah di Indonesia periode 2016-2019.

$\mathrm{H}_{5}$ : Diduga Inflasi secara parsial berpengaruh signifikan terhadap Return on Assets (ROA) pada Bank Umum Syariah di Indonesia periode 2016-2019.

\subsection{Metode Penelitian}

Penelitian ini menggunakan pendekatan kuantitatif yaitu data yang diukur dalam skala numerik, data dikumpulkan berdasarkan pada runtun waktu (time series) (Mudrajad Kuncoro, 2017: 23-24), yang berhubungan dengan variabel yang mempengaruhi Return on Asset (ROA) yang terdiri dari analisis pengaruh kewajiban penyediaan modal minimum (KPMM), beban operasional pendapatan operasional (BOPO), financing to deposit ratio (FDR), dan Inflasi, jadi data yang digunakan dalam penelitian ini adalah data sekunder. Penelitian ini dilakukan dengan menggunakan data laporan keuangan Bank Umum Syariah di Indonesia dalam jangka kuartal yaitu pada kurun waktu empat tahun, yaitu dari Tahun 2016 sampai tahun 2019. Sampel penelitian adalah dari sebagian elemen/unsur yang ada dalam sebuah wilayah penelitian atau wakil dari populasi (Azuar Juliandi \& Irfan, 2013: 51). Sedangkan sampel dari penelitian ini yaitu Bank Umum Syariah di Indonesia, dan sampel yang diambil adalah bagian dari jumlah populasi laporan keuangan yang dipublikasikan selama empat tahun dari tahun 2016 sampai tahun 2019. Metode pengumpulan data yang sesuai digunakan dalam penelitian ini adalah metode dokumentasi. Dokumentasi adalah menyelidiki rekaman-rekaman data yang telah berlalu (past). Ada 2 bentuk pengumpulan dokumentasi, yang pertama dokumentasi tertulis (printed) yaitu terdiri dari: buku, majalah, dokumen, peraturan, notulen rapat, catatan harian, jurnal, artikel, skripsi, tesis, dan laporan dan yang kedua dokumentasi elektronis (nonprinted) yaitu terdiri dari: situs internet, foto, micrifile, disket, cd, kaset, atau peralatan audio visual lainnya (Azuar Juliandi \& Irfan, 2013: 71).

Teknik analisis data dalam penelitian ini meliputi Uji normalitas, Uji asumsi klasik yang terdiri dari uji multikolinearitas, uji heterokedastisitas, dan uji autokorelasi dan uji hipotesis yang terdiri dari uji model R2 (koefisien regresi), uji f (uji model), uji t (uji parsial). Adapun model persamaan regresi berganda adalah sebagai berikut:

$$
\mathbf{R O A}=\boldsymbol{\alpha}+b_{1} \mathbf{K P M M}+b_{2} B O P O+b_{3} \mathbf{F D R}+b_{4} \mathbf{I N F}+\boldsymbol{e}
$$

Dimana,

$\begin{array}{ll}\text { ROA } & =\text { Return On Asset } \\ \alpha & =\text { Konstanta dari persamaan regresi } \\ \mathrm{b}_{1}, \mathrm{~b}_{2}, \mathrm{~b}_{3}, \mathrm{~b}_{4} & =\text { koefisien regresi dari masing-masing variabel } \\ \mathrm{KPMM} & =\text { Kewajiban Penyediaan Modal Minimum }\end{array}$




$\begin{array}{ll}\text { BOPO } & =\text { Beban Operasional terhadap Pendapatan Operasional } \\ \text { FDR } & =\text { Financing to Deposit Ratio } \\ \text { INF } & =\text { Inflasi } \\ e & =\text { Standar error }\end{array}$

\section{HASIL DAN PEMBAHASAN}

\subsection{Hasil Analisis Data}

Uji hipotesis digunakan untuk menguji hipotesis penelitian yang telah dirumuskan sebelumnya, yaitu untuk mengetahui pengaruh variabel Kewajiban Penyediaan Modal Minimum (KPMM), Beban Operasional Pendapatan Operasioanl (BOPO), Financing to Deposit Ratio (FDR), dan Inflasi terhadap Return on Asset (ROA).

\subsection{Pembahasan}

a) Pengaruh Kewajiban Penyediaan Modal Minimum (KPMM), beban operasional pendapatan operasional (BOPO), financing to deposit ratio (FDR), dan Inflasi terhadap Return on Asset (ROA).

Uji F digunakan untuk menguji apakah seluruh variabel-variabel independen yang dimasukkan dalam model regresi secara bersama-sama berpengaruh terhadap variabel dependen (Ghozali, 2018:98).

\section{Uji F}

ANOVA $^{b}$

\begin{tabular}{|c|c|c|c|c|c|c|}
\hline \multicolumn{2}{|c|}{ Model } & $\begin{array}{l}\text { Sum of } \\
\text { Squares }\end{array}$ & $\mathrm{df}$ & $\begin{array}{l}\text { Mean } \\
\text { Square }\end{array}$ & $\mathrm{F}$ & Sig. \\
\hline \multirow[t]{3}{*}{1} & Regression & 187.710 & 4 & 46.927 & 147.296 & $.000^{\mathrm{a}}$ \\
\hline & Residual & 16.248 & 51 & .319 & & \\
\hline & Total & 203.958 & 55 & & & \\
\hline
\end{tabular}

a. Predictors: (Constant), INF, BOPO, FDR, KPMM

b. Dependent Variable: ROA

\section{Sumber: Data Sekunder, diolah dengan SPSS 16.00.}

Pembuktian hipotesis 1 dilakukan dengan uji F. Berdasarkan Tabel 4.9. diperoleh $\mathrm{F}_{\text {hitung }}=147,269>\mathrm{F}_{\text {tabel }}=2,77$ atau signifikansi $0,000<0,05$ yang berati adanya pengaruh yang signifikan antara Kewajiban Penyediaan Modal Minimum (KPMM), Beban Operasional terhadap Pendapatan Operasional (BOPO), Financing to Deposit Ratio (FDR) dan Inflasi secara simultan terhadap Return on Asset (ROA). 
Dengan demikian hipotesis 1 (satu) yang menyatakan "Kewajiban Penyediaan Modal Minimum (KPMM), Beban Operasional terhadap Pendapatan Operasional (BOPO), Financing to Deposit Ratio (FDR) dan Inflasi secara simultan terhadap Return on Asset (ROA) pada Bank Umum syariah di Indonesia Periode 2016-2019" dinyatakan diterima.

b) Pengaruh Kewajiban Penyediaan Modal Minimum (KPMM) terhadap Return on Asset (ROA)

Pembuktian hipotesis 2 (dua) dilakukan dengan uji t. Berdasarkan Tabel 4.9. dihasilkan $t_{\text {hitung }}=1,980<t_{\text {tabel }}=2,00665$ atau signifikansi $0,053>0,05$, yang berarti tidak terdapat pengaruh yang signifikan antara Kewajiban Penyediaan Modal Minimum (KPMM) secara parsial terhadap Return on Asset (ROA). Dengan demikian hipotesis 2 (dua) yang menyatakan "Diduga Kewajiban Penyediaan Modal Minimum (KPMM) secara parsial berpengaruh signifikan terhadap Return on Asset (ROA) pada Bank Umum Syariah di Indonesia Periode 2016-2019" dinyatakan ditolak.

c) Pengaruh Beban Operasional terhadap Pendapatan Operasional (BOPO) terhadap Return on Asset (ROA)

Pembuktian hipotesis 3 (tiga) dilakukan dengan uji t. Berdasarkan Tabel 4.9. dihasilkan $t_{\text {hitung }}=-|22,506|>t_{\text {tabel }}=2,00665$ atau signifikansi $0,000<0,05$, yang berarti terdapat pengaruh yang signifikan antara Beban Operasional terhadap Pendapatan Operasional (BOPO) secara parsial terhadap Return on Asset (ROA). Dengan demikian hipotesis 3 (tiga) yang menyatakan "Diduga Beban Operasional terhadap Pendapatan Operasional (BOPO) secara parsial berpengaruh signifikan terhadap Return on Asset (ROA) pada Bank Umum Syariah di Indonesia Periode 2016-2019" dinyatakan diterima.

d) Pengaruh Financing to Deposit Ratio (FDR) terhadap Return on Asset (ROA)

Pembuktian hipotesis 4 (empat) dilakukan dengan uji t. Berdasarkan Tabel 4.9. dihasilkan $t_{\text {hitung }}=3,693>t_{\text {tabel }}=2,00665$ atau signifikansi $0,001<0,05$, yang berarti terdapat pengaruh yang signifikan antara Financing to Deposit Ratio (FDR) secara parsial terhadap Return on Asset (ROA). Dengan demikian hipotesis 4 (empat) yang menyatakan "Diduga Financing to Deposit Ratio (FDR) secara parsial berpengaruh signifikan terhadap Return on Asset (ROA) pada Bank Umum Syariah di Indonesia Periode 2016-2019" dinyatakan diterima.

e) Pengaruh Kewajiban Penyediaan Modal Minimum (KPMM) terhadap Return on Asset (ROA)

Pembuktian hipotesis 5 (lima) dilakukan dengan uji t. Berdasarkan Tabel 4.9. dihasilkan $t_{\text {hitung }}=1,198<t_{\text {tabel }}=2,00665$ atau signifikansi $0,236>0,05$, yang berarti tidak terdapat pengaruh yang signifikan antara Inflasi secara parsial terhadap Return on Asset (ROA). Dengan demikian hipotesis 5 (lima) yang menyatakan "Diduga Inflasi secara parsial berpengaruh signifikan terhadap Return on Asset (ROA) pada Bank Umum Syariah di Indonesia Periode 20162019" dinyatakan ditolak. 


\section{PENUTUP}

Hasil penelitian ini menunjukkan bahwa secara simultan, KPMM, BOPO, FDR, dan Inflasi berpengaruh signifikan terhadap besar kecilnya Return on Asset (ROA) pada Bank Umum Syariah yang ada di Indonesia. Secara parsial, BOPO dan FDR memberikan pengaruh yang signifikan terhadap Return on Asset (ROA). Sedangkan, KPMM dan Inflasi tidak berpengaruh signifikan terhadap Return on Asset (ROA). 


\section{DAFTAR PUSTAKA}

Almunawwaroh, Medina dan Marliana, Rina. 2018. Pengaruh CAR, NPF dan FDR Terhadap Profitabilitas Bank Syariah di Indonesia. Amwaluna: Jurnal Ekonomi dan Keuangan Syariah. Vol. 2 No. 1 January 2018 Page 1-18 Online ISSN : 25408402.

Anggreni dan Suardhika. 2014. Pengaruh Kecukupan Modal, Dana Pihak Ketiga, Suku Bunga Kredit dan Risiko Kredit Pada Profitabilitas. $\boldsymbol{e}$-Jurnal Akuntansi Universitas Udayana, Hal. 27-37.

Brigham, Eugene F dan Houston, Joel F. 2010. Dasar Dasar Manajemen Keuangan. Edisi 11. Jakarta: Salemba Empat.

Dendawijaya, Lukman. (2009). Manajemen Perbankan. Ghalia Indonesia, Jakarta.

Djohanputro, B. 2006. Prinsip-Prinsip Ekonomi Makro. Jakarta: PPM.

Dwijayanthi, Febrina dan Naomi Prima. 2009. Analisis pengaruh Inflasi, BI Rate, dan Nilai Tukar Mata Uang terhadap Profitabilitas Bank Periode 2003-2007. Karisma, Vol. 3 (2): 87-98.

Edo, Delsy Setiawati Ratu dan Wiagustini, Ni Luh Putu. 2014. Pengaruh Dana Pihak Ketiga, Non Performing Loan, dan Capital Adequacy Ratio terhadap Loan To Deposit Ratio dan Return On Assets Pada Sektor Perbankan di Bursa Efek Indonesia. E-Jurnal Ekonomi dan Bisnis Universitas Udayana 3.11 (2014) : 650673 ISSN : 2337-3067.

Ferdinand, Agusty. 2014. Metode Penelitian Manajemen. Semarang: Badan Penerbit Universitas Diponegoro.

Huda, Nurul et.al. 2019. Pengaruh DPK, NPL DAN BOPO Terhadap Profitabilitas Perbankan yang Terdaftar DI Bursa Efek Indonesia. Fakultas Ekonomi dan Bisnis Universitas Islam Malang. E-JRA Vol. 08 No. 08 Agustus 2019.

Husaeni, Uus Ahmad. (2017). Analisis Pengaruh Dana Pihak Ketiga Dan Non Performing Finance Terhadap Return On Assets Pada BPRS Di Indonesia. EQUILIBRIUM: Jurnal Ekonomi Syariah Volume 5, Nomor 1, 2017, 1 - 16 P-ISSN: 2355-0228, E-ISSN: 2502-8316.

Kasmir. 2012. Dasar-Dasar Perbankan. Jakarta: PT. Raja Grafindo Persada.

Kasmir. (2015). Pengantar Manajemen Keuangan. Kencana, Jakarta.

Kuncoro, Mudrajad. 2013. Metode Riset untuk Bisnis dan Ekonomi. Edisi Keempat. Jakarta: PT Erlangga.

Mismiwati. (2016). Pengaruh CAR, NIM, BOPO, LDR dan NPL terhadap ROA (studi pada PT. BPD SUMSEL BABEL) . I-Finance Vol. 2. No. 1. Juli 2016.

Setyaningsih, Cornelia Aryani et.al. 2018. Analisis Pengaruh Suku Bunga, Inflasi, dan Nilai Tukar Rupiah Terhadap Profitabilitas Bank Umum Swasta Nasional di Bursa Efek Indonesia. Program Studi Manajemen Fakultas Ekonomi Universitas Slamet Riyadi Surakarta.

Sodiq, Amirus. Analisis Pengaruh Inflasi, Produk Domestik Bruto dan Jumlah Uang Beredar terhadap ROA Bank Syariah. Equilibrium, Vol. 2, No. 2, Desember 2014. 
Sugiyono. 2010. Metode Penelitian Kuantitatif, Kualitatif dan R\&D. Cetakan Ke-23. Bandung: Alfabeta.

Sukirno, Sadono. 2012. Makroekonomi Teori Pengantar. Rajagrafindo, Jakarta.

Sulistyorini, Utami Tri. 2017. Metode Penelitian: Kausal-Regresi. Semarang: Politeknik Negeri Semarang.

Sumarlin. (2016). Analisis Pengaruh Inflasi, CAR, FDR, BOPO, dan NPF Terhadap Profitabilitas Perbankan Syariah. ASSETS, Volume 6, Nomor 2, Desember 2016: 296-3.

Tristiningtyas, Vita \& Osmad Mutaher. 2013. Jurnal Akuntansi Indonesia, Vol. 3 No.2 hal: 131-145. FE Universitas Sultan Agung Semarang.

Undang-Undang No.21 Tahun 2008.

Widyaningrum, Linda. 2015. Pengaruh CAR, NPF, FDR, dan DER terhadap ROA pada Bank Pembiayaan Rakyat Syariah di Indonesia Periode Januari 2009 hingga Mei 2014. JETSTT, Vol. 2 No. 12 Desember 2015. 